\title{
Poetical Theory
}

\author{
Angela Brown \\ E-mail: brownlas6@aol.com
}

Received: 25-10-2013

doi:10.7575/aiac.ijalel.v.3n.1p.249
Accepted: 09-12-2013

Published: 01-01-2014

URL: http://dx.doi.org/10.7575/aiac.ijalel.v.3n.1p.249

\begin{abstract}
African-American literature has both been influenced by the great African diasporic heritage and shaped it in many countries. It has been created within the larger realm of post-colonial literature, although scholars distinguish between the two, saying that African American literature differs from most post-colonial literature in that it is written by members of a minority community who reside within a nation of vast wealth and economic power.
\end{abstract}

Keywords: Literary Analysis, Poetical Theory, Poetical Verse

Jackson poems bring back memories of growing up in the seventies. I feel I can relate to meaning of the imagery displayed in his poems. The seventies were from my childhood. Dad had an old Oldsmobile car. It was yellow with leather interior. Every Sunday we went to church. I was Catholic. Back then the pariserners believed in dressing up. The old ladies wore big hats to church. Back then church was a fashion show for the Lord. It was pertinent for the family to praise and thank the God for the blessings in our lives. Boys would hang out at the school to play basketball, while the girls double ditched and played hop scotch. The dress attire was different. The girls wore low cut jeans as a fashion statement. We would walk to the neighborhood candy lady to buy now a laters, blow pops and candy. The old men hung out at the corner store playing checkers. The drug dealers lived lavishly. The girls I knew had an idea of which they were to marry and how many kids they had. A fatal attraction started at an early age. The housing was poor on the West side. We had tin top roofs that would make a special sound when it rained. I don't think Vegas were no different to Philly during those times.

Dungy's poems are archaic. His poems touch a sensitive area for me to read. I since Dungy had a precarious life as a gay man. He describes his sexual experiences as forbidden to secrecy. I can relate to his poems being a victim of abduction by my brother since an early age. It was a feeling I resent. It was incest which is a sin. How Dungy describes his moral faith with God is a truancy of empathy. I feel that he also resents his sexuality choice he made. I find his poems sensitive in defining my sexuality, because, I chose to be a virgin until after I marry. I am 44 years old and I am a virgin. I never consented in sexual sex acts or intercourse. It is my Catholic faith that I chose to be this way, because, I am uncomfortable with engaging in sex. It is surprising that so many men who were abducted in the Catholic Church as young boys also resent it. I feel Dungy is defining his sexuality at a time that people are admitting to be openly gay in the military and President Obama wants to permit same sex marriage.

Young's poems are very diverse. Young speaks about how relationships founder between broken friendships. He speaks about love and adultery as being pervious to life experience. Young tells about how authentic lovers are subservient to nature. Young wrote about black male hair in how thick, curly and beautiful it is.

The similarities in Jackson, Dungy and Young's poems have something in common. There poem are reflective of a younger audience who can relate to the ambivalence of the message they are trying to convey in the poetry. Each poet is pungent in how they create empathy towards conflicting interest. The message each poet is conveying is saying something that is not commonly spoken to create awareness of something that is sensitive to understand. The message they convey is something that has to be said. The message has to be told. It is recording history of our times. It is recording a social condition reflective of our society. The people who read their poems are looking for gratification of an artistic craft.

Lord's poems relay a hidden message mortification of sin. Lord speaks of adultery of how her father had more than one relationship while being married. Lord speaks about how she needed her real mother in her life. Lord speaks about finding her own identity through the entire disturbance in her life.

McElroy's poems are reflective of black mannerism. McElroy uses tradition to define black culture in her poems. McElroy's poems reflect the social graces of the south in how women are perceived to be. She discusses the foundation of human experience to relay the message of human consent.

Knight's poems speak of so much anger and hostility in it his poems become an imagery of containment. Knight comes from the Civil Rights era and his poems are a reflection of an understatement of surrealist thought processes. Knight undermines life for hidden ailment of regret. I feel that in his era it is a reflection of mystery from not knowing the outcome of what is expected of black people of his generation. 
McKay's poems are lyrical poems of organized behavior. McKay's poems are a lethargic ensemble of patterns. The patterns describe the emotions of black people during hectic times of a transitional movement. He addresses issues during this time period as mosaic creating apathy towards his subject matter. The message he is conveying is painful and morbid.

Baraka's poems are an apithamy of realism. Baraka relates to his subjects from experience. I find some of the language in his poems vulgar and offensive. I disagree with the usage of synergy and violence in his poems as a defect of love.

The Similarities. Lord, McElroy, Knight, McKay and Baraka's poems are about relationships. The poems are written on the hardships of blacks during their era. Often they speak about a negative response which alienates a persona of euphemism. The message the poets are sending is of regret and change. The poets speak of an ambivalence of power and restraint through their protest.

Angela Brown. I feel that my poems have something in common with these other poets I have discussed, because, I write about an ailing relationship of black people who have suffered through their struggle as a race. I talk about in my poems relationships with family that have faltered; yet, remain strong because of the love that generates inside of our hearts. I talk about the pain of hard times I experience growing up living in poverty and surviving neglect and abuse with the gift of hope that things will change. I write poems for others to understand and relate to my condition and create a since of awareness and change. I want others to feel a since of pride in who they are. I want to inform others that there is someone out there that feels and understand their weaknesses.

Angela Brown Style. Every poet has their own writing style. Kevin Young's poems is written differently than my style, because, I have my own nitch for writing. I write in free verse. My poems are strong because of the analogy message it contains. The placements of the words in my poems create added meaning to the poem. There are painters who apprentice other artist; but, they have their own style of painting. It is the same way with poetry. I use words to convey a message that is unique than other poet's style. I feel that once I have developed my own technique, that I should foster my style by transforming my craft of writing. I can do this by reading other poets work. I can see how other poets use words to convey meaning to what they write; but I have my own vision on what my life experiences are all about in how I relate to the world. This is what makes my writing a different style than other poets. I am glad to express myself. I feel good to use my own thoughts and feelings in my poems. I feel I am a spokesperson from my generation. Jackson and McKay express them openly similar to how I feel. They use free style words in their poems. Their poems are free verse. I feel strongly when I read their poems. I can identify with the words they use in their poems.

Lucile Clifton is my role model. I have been admiring her style of writing because of the physical contact she has with reality. Lucile creates a setting that is realistic. My favorite poem she wrote is, "Kitchenette Building." I have never lived in an apartment with my family; but how she uses imagery to create an affectionate setting is realistic. Another poem Lucile wrote, "Homage to My Hips," translates black pride in women that her hips are special. Patricia Smith is also a role model. I like her poem, "Burial," because I relate to it. I can understand with the morality of the poem assonates the responsibility of taking care of our people even at the time of death. I would not prefer to use some of the profanity the men use in my writing. I feel men view life differently than women. When I write a poem I want it to convey a message of hope. I write dark poetry from experience in a different approach than Kearny or Ealey. I feel the reader's response should be a habitual reflection on life instead. As socialist, we should create a climate for our readers to perceive dialect and form.

The Community of poets express what confronts us as a unit. The community involves more than just race, gender and social construction. The poems the dialect teaches a structure of conformity and discipline of a culture. The poems are perceived to be uniform with how we identify with being Americans as a melting pot. As Americans we come from a common belief that we are no different than any other American, when we are confronted with social conflict. We all feel pain, sorrow, happiness, love and anger so we learn from our mistakes and heal from our pain. 911 was an example of the American faith. We came together for a reason. The reason Americans bonded was because of the meaning of determination. It is something as a country has struggled with since the American Revolution. I feel how we see others are how we perceived to be. America is a resilience of our own reflection. The poems are archaic speaking of the ailment of human strength and hope. The poems speak of honest humility. The poems are a reflection of society norms which others can identify with granting empathy and understanding to issues readers do not understand. The poems message states this is who our community is as a people in that we are no different than others. It expresses poets are human and poets have feelings too. Poets are a group of writers who want to be understood and respected. I feel that we are all humans. There is good and evil in everyone. We must learn to look beyond human value to replace with personal ambition and determination to define who we are. If we are afraid to define who we are, we die as a community. It is important for writers to perceive things differently, because, with reason we change in time. Let us not wait for time to defy reason in who and what we have become.

I write about my cultural experience on cultural diversity and social conventions in society. I feel I have a lot of anger inside that I want to come to understand my purpose. I grew up poor and the students teased me about this. I had an abusive mom who made me feel suicidal. I feel mom took her anger out on me because my parents were going to get a divorce. She wanted me to stay with my dad and my brother to stay with her once they were separated. I was sexually abducted by my brother at a young age. I resented it; but I loved my family. Out of alienation, I grew up angry at God and myself for not understanding my purpose in life. I was a loner in school. I knew people and had no friends. I did not grow up racist. I could cope and get along with everyone. I was being told off and made fun of. This hurt. Morally it was wrong. Being suicidal I lost every friend I had known in college and was making more enemies because of my 
grades. At this point, I wanted to know what it meant to be black and so each research paper in college was about my race. I had seen a psychiatrist for several reasons. One of them was because they denied I had an ability to write. The other reasons were because I needed someone to talk to, because, I felt suicidal because I was going to flunk out of school. I always loved school because, my parents were educators. It was when I had my first poetry class that I realized I wanted to write poetry. I started to read great poets such as Dickenson, Plath, Frost, Browning, Angelou, Hughes, Giovanni and fell for their craft. It a teacher and psychiatrist wanted me to fail because of my writing, I wanted to pursue writing poetry. My first group of poems which were published were about black pride. There was a need for me to not be ashamed of being black, but being proud of who I am. I became a cultural activist who wrote about racism during my generation in how I reflect on images which society dictates. It became a time when I wanted to reach an audience to feel the struggle of my race in this generation. This generation where blacks thought it is cool to go to jail. It is a generation where lot of boys and girls who get locked in prison. It is a generation of a large population of aids victims. It is a generation where single women have to raise a family alone. It is a generation of the poverty gap is large amongst blacks. It is a generation of high drop-out rates in school. It is a generation of girl prostitution. High rate of gays and lesbian women who live privately outside the church. I am reflective to our troubled youth that a black poor person can become an educated poet as an inspiration to young readers.

Angela Brown was born on January 5, 1969 in Meridian, Mississippi. Angela is a poet fellow and poet ambassador. Angela is on the board of poetry for Kentucky, University. Angela is an editor for IJALIL journal of literature. Publish America has listed Angela as Who's Who in American Literature. The Library of Poetry named Angela as Who's Who in Poetry, Hall of Fame in poetry, Poet scholar and Poet Laureate. Angela graduated the first in her family majoring in General Studies at Clark County Community College. Angela was the first to graduate wish a Bachelor of Science degree in Post-Secondary Workforce Education. Angela has two honorary doctorate diplomas in Humanities and Fine Arts \& Communication. Angela has been published by the Library of Poetry anthologies. Angela is published by Black Crow, Caloloo, Pendleton, Black History anthology, African American Registry. Angela's first poem was published by the Sentinel Voice Newspaper, CCCC Red Rock Review, CSN student paper, UNLV student paper. Angela has books published by Durance publishing, Air leaf publishing, Publish America and Outskirt press publishing. Angela journal entries include the national journal network, IJALIL journal, Columbia journal. Angela poems are published by Affilia, LKDN, Scribd and academia. Angela has published lesson plans on poetry. Angela poem lesson plans appear on the edu2 web page. Angela has written articles for the Las Vegas Sentinel Voice Newspaper, the National Press club, Newsweek, New York Times and Helium. Angela has written over 20 published books around the world. Angela has won script writing contest from Skyfest, Act One, the Black Screen Writers Association, Fade In Line. One of her screen plays was accepted by Warner Brothers. Angela has a documentary from her fictional biography, "A Walk Together," with Publish America. Angel is learning disabled. Angela Brown aspires to be a professional writer and to teach Creative Writing. Angela is a political and cultural activist. Angela song label will soon appear with Little Wayne web site. Several of my songs went to the grammys. I was an applicant for the Cave Canen Fellowship, the Borens Fellowship and, the NEA fellowship. I was an applicant for the book award with NAACP Image awards, the Loretta Scott King Jr. award, the Pulitzer award, and the Hurston/Wright book award. I won the Writer's Digest book award twice. One of my books made the best sellers list. I have done hip hop poetry, poetry slam and underground rap poetry. I aspire to be an English instructor or a librarian.

Intro: I like to read poetry and short fiction. The types of poems I like to read are from the Harlem Renaissance. My favorite poets are Nikki Giovanni, Maya Angelou and Langston Hughes. I also like to read other famous poets modern poem anthologies. I read poetry every week to study the poet's style and craft. My favorite poem by Nikki is Cotton Candy on a Rainy Day. My favorite poem by Angelou is Why the Caged Bird Sings. My favorite poem by Langston is America. I like Gwendolyn Brooks's poem Kitchenette. I also like Browning, Frost, Plath and Emily Dickenson. I find myself writing once a week. I pressure my thought process to think, read and to write poetry. Poetry is like therapy for me. I write about cultural issues reflected of my Las Vegas culture in how I relate to having mental illness. Some African American instructors consider my form of writing like Civil Rights poem. A Resolution is a poem written about the social conventions of African American struggle for cultural diversity. America is a poem written about the struggle for African Americans in our conquest to having equality. When I write I am happy for others to reflect on my ideas and relate to them in their own way. My short term goals is to express myself with clarity in my poems. My long term goal is to develop a quality poem to get my poems published.

\section{A Resolution}

Yet deterred, by fate alone

Many questionable conclusions, theories, details

Yet to determine who is the blame

A resolution, only to retroact an opposition

Yet to insist the muddied possibility for change 


\section{America}

If I die, let it not be in vein.

For whom I am, I am not ashamed.

For what I'm not, for who is to blame?

For praise and glory, I have yet claimed.

For all the sins, indebted to my name,

For bitter hatred, cries and pain,

I made my choice, with sovereign reigns,

For my fate deterred, its meaning estranged.

\section{At 44}

At 44, my strands of hair become thin and grey and the skin begins to darken like darted fists underneath my eyes and the gentle skin I had as a child becomes wrinkled like a crunched, paper bag and my gums soft holds my teeth with many fillings and loss of memory dissolves in fractures of disturbed imagery from lost dreams and lost ties become a shattered universe of unsorted, ragged premises in untimely space and health is a means of retaining a sound mind in all the chaos of maintaining order in my life and at 44, I wait for answers that have been long forgotten and I wait for signs, it is what I want to believe in and for those who depend on me is the reason for why I live and old age is when loneliness becomes an inevitable truth to escaping insanity

By, Angela Brown

\section{A Milestone}

Look not on what you have succumbed; yet seek to determine your destiny.

Know not the tolerance failure brings; but, to measure your ability.

Listen to emotions softly unfold; to quietly defuse self-hate.

Inhale love within grasp; for life encounters many mistakes.

Cherish the need to be loved; for you only have one chance.

Develop who you are, and what you lose becomes circumstance.

By, Angela Brown

\section{Becoming, By Angela Brown}

I tip toe through shattered glass,

A broken bottle of a washed dream.

Wept blood flows through the streets,

With another token of apathy.

Another uncomfortable imposition

Left behind a mellow, cold heart.

Emotions pardon, as

My heart cries from the

Pleasures we never consumed.

Each moment is too intense

To deny, you will never love me.

You managed to puncture

A wound in my heart, because

You control me.

A clay, ceramic bowl is broken.

I surrender my love to you.

\section{Lovers, By Angela Brown}

A relationship will hold water in its cusp, 
An understatement to many sleepless nights.

I am the measurement of hard times of matter,

From the amount of hours we spent together.

I ponder with unending emotion,

Through concurrent times. Many nights I attempted to

Contemplate suicide, as you watched me

Afraid to die in my sleep.

\section{Prison}

I pace, I pace my steps

Walking back and walking forth

I stand tall casing four blank walls

Each step I take in modesty.

Fidgeting hands, bad nerves

Fidgeting, anticipating the voices in my head.

Silence, I stare at a vacant room.

I answer my voice calling, calling, calling

Afraid of what I think, words trash back at me.

I must contain my hands,

I place them in my pockets.

I realize I am alone, alone

I contain my composure.

Silence I contemplate a motive

Trapped in an isolated

Asylum

By, Angela Brown

\section{Forgiven, by Angela Brown}

Navigate the currents, I am intolerant to pain. The current drifts of abuse, by the women I love. Empty air could not filter the lashes of the whip that made me suicidal, of the physical abuse. Maybe I will wait for the messiah, to tell me I am a strong woman. The jealousy of her pilled the black off my skin. I followed her instruction, for I honored her integrity. The roots of terror stocked my troubled conscience. It was a terrible thing. Hoping things could be different. She chose my friends. She chose who I was to marry. It came with the package of child birth. As a turtle, I dragged behind all the garbage that sprang up. I waited the path to finding peace from her verbal abuse saying that I would not amount to nothing. From the voices in my head that I was not worth shit as I gazed down and was slapped in the face. Remembering the thoughts, I became weak scorned from happiness. She told me I dishonored her. I was to obey her. She owned me. Anyone who got close would be doomed for I was not worthy to be their friend. Deep in my heart, I knew this experience with my Mother; but what would make me a better person or break me. Now, a light flickers in the room, to replace the guilt, I'd long forgiven.

\section{A Mother's Relationship, by Angela Brown}

Touched by an angelic figurine,

Mother's soul will travel in space.

The intimacy of our relationship is unfounded.

The fluid that slithers in water underneath my feet

Is the energy generated from a Mother's love.

It is the love that surpasses time.

My love for her will clasp the sun, while

The weight of life measures to exist within the galaxy above.

Our relationship will always remain with good reason,

For she is the pendulum of hope, I aspire. 
Dad's Guitar, By Angela Brown

Dad's a shadow, a ghastly spirit,

I have yet, come to know.

The cold, moist air aroused his temperament,

In which he hung his hat, we call home.

An authentic office, provided support

Each etching that made a difference.

He flicks his fist out of anger,

Demanding respect, to mark his territory.

A guitar picks his last note,

A quarter note, a flat note, a rest note,

As he thumbs away into uncertain space -

Now silence.

Issues, By Angela Brown

My Dad has issues, he abandoned death, absent to life.

Wisely reaching out, longing for rain to touch his tongue.

His bitter empty heart, swelters his state of mind.

Clamping his soul with guilt, under the eve of deception.

The moment of remission will harness his fate.

For his desire to release affection, remains a matter of substance.

A Relationship with Time, By Angela Brown

Our youth is trying

to escape time,

Running, running

before time is out.

Stumbling amongst

obstacles of redemption.

Failing to understand

what is circumstance.

There is no schedule,

no plan,

no strategy.

Their fate is based

on a map,

Sketched in

their minds

in a language

They cannot read.

\section{Silent Rivalry, By Angela Brown}

Dedicated to my niece

Silently, nature calls out

The scent of pine cones filter the air

The sweet smell from grass cover the ground

Trees whistle in the wind

Another Christmas passes

The winter chills through the home

Snow covers the land with frost 
A child has passed another season in prayer

"God bless, my family"

All she has is her mother's love

\section{Word Practitioner, By Angela Brown}

Dedicated to Maya Angelou

Give me your hand

Let me interpret words of wisdom

Guide me to communicate phrases

To develop the freedom of expression

Nurture my passion to listen

To remediate music through meter

Grant me the ability to interpret

The language of humiliation

Guide my mind to escape imagination

To feel a dream of compassion

Brotherly Love, by Angela Brown

In dedication to my brother and all other brothers

It only takes a blank sign to question

A kind heart with a one word phrase

A vivid imagination with a quick nod

A mad mind to sear a gentle conversation

A blank stare to act a simple gesture

An eager need for mediation

A question is the final query to recognize

My need for love

\section{Bird in Hand, By Angela Brown}

In dedication to the love of my life

My gift to you is circumstance

A pondering of psalm

I speak with truth and somber thoughts

To dictate essence of songs

I speak with grand fertility

To have you to myself

I light a candle to give you praise

Under what faith was built

And with God's consent

The choice is ours to make

Save the hideous mistakes

From our past, I ask of fate

To rancor our innocence

\section{A Fatal Attraction, By Angela Brown}

In loving memory of my first lover

Where did it all start?

We fell between sins 
We were fools in love

Why did it end?

Our love was naïve

To have thought

We fell in love

From the very start.

Love is not the same

There were missing parts

A mere misunderstanding

We had to part.

The deed is done

A mere mistake

We must learn from loss

To know our fate.

\section{Biography of a Black Woman, By Angela Brown}

1. Cultural Diversity: A diverse group of women who have common interest in learning how to develop the community to become a better place. Women in this community questions things they do not understand. Women try to change conditions which are detained. Women control their fate peacefully.

2. Breaking the glass ceiling: Women who want to be considered equal to men and are trapped in a social convention which will not let them free. This community of women embraces conflict to reach their goals to unknown consequences.

3. Human Conventions: A human convention is where there is an outside force that controls your life from having absolute freedom. This community determines convictions of opposition by teaching integrity through experience to create a civic awareness to conflicting issues.

4. Moral Activist: A leader who leads their life, according to their religious faith. Women in this community have a foundation which determines their character by asserting reason and giving empathy to sensitive issues they confront on the daily basis.

The Slave Curse, By Angela Brown

I am ashamed of who I am.

My past is cursed from slavery.

My heart pleads silently afraid.

I am soft spoken, I cry somberly.

I am confused of who I am.

My heart shattered of one thousand times.

I am confused of my moral faith.

My soul stripped of integrity.

My head bowed down to my senses.

I burry my burdens before God, to be forgiven.

What if Means to be Black, By Angela Brown

Being Black means that you look them in their eyes to be ignored

It is a disease when your skin in dark and inferior to other skin

It is when they whisper silently of oppression against you

It is how they degrade you for being poor

It is where they spread rumors you will always regret

It is when the pain in your heart cries every night plotting suicide

It is a feeling where you are neglected for being unacceptable 
It is to live your life day to day without expression

Being black is the feeling of being alone because no one really listens

Being black to me, means to be out of touch with reality

\section{In Your Own Skin, By Angela Brown}

Being light skin, people will support your goals

It is when you pass people nod and greet you

It is when they accept you for who you are

It is when people will support your dreams

It is when people hold good intentions for you

It is when your outlook on life is always positive

It is when people show interest in you

It is to live a blessed day everyday

Being light skin is a feeling that people care

Being light skin to me, means you are loved.

\section{Soul Mate, By Angela Brown}

When your man has come back from prison, you must beware of him for he is not the same man you knew when he left you pregnant. He is not a whole person. His spirit within him if full of anger. Different from the pride he had when he became a father, for he is now full of shame. He is embarrassed that he once envied his father for being a man and now he is belittled for being half the man who cannot support his own family. He has guilt within him, for he cheated on you when he stole to support his family. Going to prison was a noose, chained him in shackles which enslaved him for ten years for a crime he said he did not comment. "I did nothing to nobody, officer." For ten years he wore a scar that said, "Whore." He was being marked a demon for the color of his skin was the color of charcoal. "Guilty as charged." Prison took away the respect he had as a free man. The prison, he must learn to survive in hostility, a slave to the master guard's command. Branded a number on his uniform. The prison number became his name. He must learn to fight to survive. He had nothing else to live by. When he returned home, he must take the agility of self-hate, to learn to love his family he had lost fate in the prison ward. His wife must learn to cleanse his scar and nurture his soul to return home knowing he is somebody and that his family loves him for that is all that matters. He has come home to a family who accepts him and loves him.

\section{Slavery, By Angela Brown}

In the land I come from, I am free to roam the savanna to hunt. I am able to demonstrate my man hood through rite of passage. Today, I wonder about to find something to make a drum. I am captured. I am taken by a rival enemy. I am shackled and chained to the bottom of a ship. For months I travel by sea. Extra cargo is thrown overboard. Some are sickened from the fetus and vomit. We Africans speak different tongues and cannot communicate. I stand on a platform, naked. My skin is branded with a number. The number indicates who owns me. I am sold for less than a penny. I live in a foreign land, called America. I cannot escape harsh treatment. I am beaten with a horse lash. My back holds gasp of blood from the whip. If I fight back, I will be lynched, shot or burned to death. If I fled, I will be branded with an r, a runaway slave. The dogs will find me and rip my body to pieces. I ran away more than once. My punishment left me crippled. My foot was shot off my leg. I miss my family. I watched black women raped by the white man that sickened me. The slave master fucked her dry. If the women submit, there is a chance their children would be free from slavery. If my master allowed me to learn to read and write, the salt on my tongue is dry. The sole purpose of a slave is to serve. A plantation has no place for a slave to read and write. It is a threat on a plantation to read and write afraid there will be a slave revolt. My spirit is gone. I have no reason to live. My personal freedom is beseeched. I lie awake in my death bed. If I am a good slave, and I do as told, they may grant my freedom. I am a captive of slavery. I am betrayed by demons. I have no life as I speak. For two centuries, a life sentence, I surrender to sin. I rise to pick cotton. I live under the whip. During the revolution, to death, you cannot see what you cannot find. Afraid, as a slave, I lie still, on my death bed.

\section{The Black Community, By Angela Brown}

It takes a village to raise a child. But how am I raised, without family. My gang is my family. We come from a community of host who protect us from harm. United we stand as family. We live together. We die together. We help our brothers and sisters from destruction. We mark our community from harm's way. In our community, everyone knows when we go wrong. Our community of peers testifies in our behalf. It gives us a second chance from going to prison. The village gives us a chance to lead a moral life. Our community of peers supports us, to gain success. We acknowledge our own kind. We are a community of faith, who thrive on faith, making life a better place to live. 


\section{Rosa Parks, By Angela Brown}

It was a historic day,

The clouds were dark and heavy

It was a day of apithamy.

Blacks were second class

Citizens. You read it. The signs said

No blacks allowed. Blacks were not

Permitted in public domains. The law

Read separate; not equal. Blacks

Were to give up their seat for whites

To sit at the back of the bus. Rosa

May have heard the voices in her

Head, when it served her time to say

"No." 'Not today.' Rosa took a chance

That led a revolution to equal rights.

The police were waiting for to put her

In jail. Rosa broke the law. How can

A country is free, without just cause?

We are not truly free.

In the seventies in Las Vegas, a young

Boy told his sister that blacks out of respect

Must sit in the back of the bus. This girl

Too refused to give up her seat and

Realizing the just cause is an absolute right

Words of Endearment, By Angela Brown

1. Slots - Are you ready to rumble. Vegas is known for glitz and glitter. You have to be a keen eye to guide you through all the slot machines. You cannot afford to enter a casino without chump change. Every patron knows this. A rule of thumb. Beware of the noise of coins dropping out of a slot machine. Temptation has it. You are deemed to become a victim of placing a few coins every time you enter a casino. Today is your lucky day.

2. Blackjack - Once you pass the slot machine, there are the table games. You will be a sucker for gambling a hand of Blackjack. It is a $\$ 5$ dollar minimum. Surely you played 21. It is a sucker bet. The excitement builds at the table. There are people yelling. They won! There are high fives in the game. The cocktails keep your belly warm. You feel the momentum. You got to have it. Luck that is. Cha-Ching. You are in the money.

3. Craps - Your luck is running. After you played blackjack, why not play craps? Once you look around and see the table is loaded with money, you begin to feel a lucky streak. You place a prop bet and win, you feel like a high roller and so you stay to try the odds at beating the dice.

4. Sports book - After you wind down from the excitement, you will come across the sports book and it is football season. You sit at the bar and watch the game with the guys on a wide screen television. You know who you are pulling for, because like the lotto, you bet the ticket. It is the next best thing to being at the game. You have something in common at a casino. It is the fun of the game and your team is winning. You have a winning streak.

5. Comps/Lotto - You are getting hungry and you want to eat, so you got a free ticket to eat with your buddy at the buffet. You had not eaten all day and you pile the food up on your plate; but while waiting, your lotto ticket is in and you wait to hear the winning number.

6. Poker - You are tired now that your tommy is full and you want to go home, when you see the Poker room is full. You know the game you played with friends in college, only it was strip poker. You have won and you have $\$ 500$ to kill, so you buy in a game of Texas Hold'em. You have pocket Aces and it is the turn with a possible full house. The river card is the determining factor. The board plays one ace and a king. The river plays another king. You played the highest hand. Yes! You won the pot. You dedicated a day at the casino, you're tired and now it is time to go. Your pocket change just got fatter. You leave with a big poker face. What a day. 
References

Brogan, T. (1994). The New Princeton Handbook of Poetic Terms. Princeton: Princeton University Press.

Culler, J. (1997). Literary Theory: A Very Short Introduction.

Ciardi, J. (1959). How Does a Poem Mean?. Cambridge, MA: The Riverside Press. Depts.washington.edu/lsearlec/510/Texts/Olson-Outline.pdf

Drew, E. (1933). Discovering Poetry. New York: W.W. Norton \& Company.

Harmon, W. (2003). Classic Writings on Poetry. New York: Columbia University Press. 